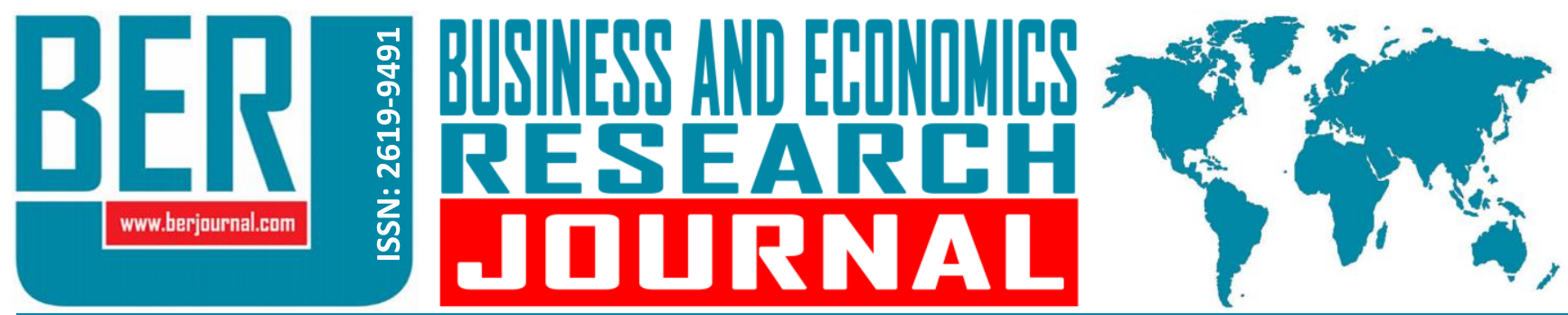

Business and Economics Research Journal Vol. 11, No. 1, 2020, pp. 1-14 doi: 10.20409/berj.2020.232

\title{
Generating Economic Growth in Countries with Migration and Fractionalization
}

\author{
David L. Ortmeyer ${ }^{a}$, Michael A. Quinn ${ }^{b}$
}

Abstract: Poverty and instability continue to plague many developing countries. Previous research has modelled economic growth and political instability simultaneously accounting for exogenous factors such as ethnic fractionalization. This study builds on that literature by using a three equation system which deals with the endogeneity of fractionalization. Another contribution is the incorporation of migration into the model. Results from a cross-country, panel data set over the years 1996-2014 find that linguistic fractionalization and migration work to lower growth indirectly via increased political instability. Endogeneity is found to be important as religious fractionalization becomes insignificant after accounting for its endogeneity. Results vary by region, with the impact of fractionalization and instability being most important in Sub-Saharan Africa. These results suggest that linguistic and religious diversity are not having the same effects on stability and growth across countries. While some policy makers in the West have expressed concern about migration and fractionalization, they do not seem related to either long-run political stability or economic growth in their countries. Migration and ethnic fractionalization should be a larger concern to policy makers in countries with weak institutions and records of political instability. International organizations and donors need to increase support to developing countries which have received large inflows of migrants and refugees, with this aid being directed towards bolstering the quality of institutions.

Keywords: Fractionalization, Growth, Migration, Instability, Aid, Institutions, Africa

JEL: 011, O43

\section{Introduction}

Economic growth is crucial to the process of economic development. Globally, growth has been uneven across regions and over time. Regions such as South and East Asia have seen real incomes multiply over the last few decades. This has led to a profound decrease in poverty rates across the region with extreme poverty falling to below $20 \%$ of the population. Unfortunately, growth across sub-Saharan Africa (SSA) has been less consistent and slower, on average. The 1960-1980 period experienced per capita growth rates of $4.8 \%$ but this fell to $2.1 \%$ from 1980-2000 (World Bank, 2018a). Since 2000, growth rates have been higher but the low level of per capita GDP is still a major problem across SSA. Of the 34 countries classified as low income by the World Bank, 27 of them are in Sub-Saharan Africa (World Bank, 2018b).

a PhD., Senior Lecturer, Department of Economics, Bentley University, Waltham, Massachusetts, USA, dortmeyer@bentley.edu (ORCID ID: 0000-0003-2524-7440)

b PhD., Professor, Department of Economics, Bentley University, Waltham, Massachusetts, USA, mquinn@bentley.edu (ORCID ID: 0000-0001-6858-9569) 
The experiences of many African countries have led research on economic growth into the issues of institutions and political instability. Good institutions can both increase economic growth and lead to more political stability (Acemoglu \& Robinson, 2012). Corruption is an important factor which can reduce political stability in a country (Mauro, 1995). And political stability is important for ensuring long-run economic growth (Roe \& Siegel, 2011).

Confronting issues of institutions, corruption, and political stability can be even more challenging in a country which has a high amount of ethnic fractionalization. A high rate of fractionalization can lead to groups competing for power and funds, increasing corruption and reducing the quality of institutions (Easterly \& Levine, 1997). This can lead to more political instability and have a negative impact on growth (Goren, 2014). The relationship between fractionalization, corruption, instability, and growth has been studied in the literature (Karnane \& Quinn, 2019).

One of the issues which has only recently been introduced into this literature is the issue of migration. An increasing number of people are migrating internationally. By 2018, the stock of international migrants stood at 244 million globally (United Nations, 2018). This increased flow of people across borders could have a multitude of effects. The effect of migration on economic growth may not be simply a direct effect. Migrants may impact the level of fractionalization in a country which could then impact growth either directly or indirectly via political instability. Also, a flow of migrants entering a country could directly affect political instability in a country, even if the level of fractionalization does not change. This paper will contribute to the literature by robustly testing different migration measures into this system to gauge both direct and indirect effects of migration on economic growth.

This paper adds to the literature by first testing the assumption of exogeneity for linguistic and religious fractionalization in the context of political instability and economic growth. The assumption of exogeneity with respect to linguistic fractionalization holds up to testing and so is justified. However, religious fractionalization is found to be endogenous. This paper therefore uses a three equation model rather than the two equation model used in the literature. Economic growth, political instability, and religious fractionalization are all modeled as endogenous variables. Addressing this endogeneity is important to ensure a valid modelling of the direct and indirect relationships.

The paper's empirical work finds that political instability is an important conduit for many factors impacting growth. Both linguistic fractionalization and migration are found to reduce economic growth via increased political instability. The indirect impact of migration on growth is driven by results from SubSaharan African countries, with migration and instability both being insignificant for growth outside of SSA. After accounting for endogeneity, religious fractionalization is insignificant with regards to growth. Corruption has differential effects based on region as well. The paper's results suggest the importance of controlling for the endogeneity of multiple variables in this type of analysis and for regional effects.

The next section reviews the relevant literature and develops testable hypotheses. This is followed by a discussion of the empirical work and results. The paper concludes with implications for the literature.

\section{Review of Literature}

There has been a considerable amount of research into the factors which impact political instability. Of particular importance to this study is the role that ethnic fractionalization has in determining political instability. Researchers have found that ethnic fractionalization can increase political instability (Annett, 2001). A non-linear impact was found by Blanco and Grier (2009). Their research found that ethnic fractionalization reduced instability up to a point but then could increase instability. It could also be that very low and high levels of fractionalization create less instability than intermediate levels (Ranis, 2009). Related work has found that fractionalization can lead to the under provision of public goods and increase patronage (Easterly \& Levine, 1997; Easterly, 2001; Alesina \& La Ferrara, 2005; Kimenyi, 2006; Touchton, 2013). Innovations and reform of the economy may also be blocked by elites as a result of fractionalization (Acemoglu \& Robinson, 2006). In more extreme cases, fractionalization can increase the likelihood of civil 
wars (Montalvo \& Reynal-Querol, 2005). Fractionalization affecting political instability is relevant to this study as instability can impact economic growth.

\subsection{Effect of Political Instability on Growth}

There are numerous studies on the relationship between political instability and growth. Alesina and Perotti (1993) find that political instability leads to lower growth because of decreased investment. Instability increases uncertainty which reduces investments, both foreign and domestic. This instability may also impede a country's financial development, which is important to economic growth (Roe \& Siegel, 2011). Governments which have a higher propensity to collapse have been found to experience lower rates of growth (Alesina et al., 1996). One of the most relevant papers in the literature in terms of this current study is the work by Goren (2014). Utilizing the Barro-Lee data set, Goren finds that political instability reduces growth and that ethnic fractionalization's impact on growth is direct (not indirect through affecting instability). Goren's study uses a SUR approach on five year average growth rates, treating fractionalization as exogenous and not including migration.

\subsection{Effect of Fractionalization on Economic Growth}

Ethnic fractionalization can impact growth in several ways. Ethnic fractionalization can become a source of conflict in a society. And research has found that ethnic conflicts reduce economic growth (Easterly \& Levine, 1997; Alesina et al., 2003). Research such as Mo and Papyrakis (2014) have tested the direct effect of fractionalization on growth and found it to be negative. Others such as Collier and Hoeffler (1998) propose that ethnolinguistic fractionalization works indirectly on growth by reducing trust and increasing transaction costs. Fractionalization may also impact the provision of public goods and increase rent seeking activities (Easterly \& Levine, 1997). The negative effect of fractionalization on growth is exacerbated by weak institutions (Collier 2000, 2001; Easterly, 2001). Other work has found a negative direct impact of religious fractionalization but not linguistic fractionalization on growth (Reynal-Querol, 2002). There is also research suggesting that fractionalization has a negative impact on growth, but that it works indirectly through impacting political instability (Karnane \& Quinn, 2019). These previous studies all treat fractionalization as exogenous. A related study confronting the issue of endogeneity and fractionalization is the two-equation system of Campos, Saleh and Kuzeyev (2011). This study combines linguistic and religious fractionalization into a single variable which is then treated as endogenous via instrumental variables. Campos, Saleh, and Kuzeyev (2011) is still only a two equation model, however, as their study focuses only on growth and does not deal with political instability. They also find a negative impact of fractionalization on economic growth.

The negative impact of fractionalization on growth is not a universal finding. Montalvo and ReynalQuerol (2005) did not find a direct relationship between religious polarization/fractionalization and growth. Bove and Elia (2016) found that ethnic fractionalization increased economic growth in developing countries, but not in developed countries. Their analysis did not separate out linguistic and religious fractionalization measures. But it did account for the endogeneity of ethnic fractionalization with respect to economic growth. Bove and Elia (2016) controlled for the size of migration stocks in countries on fractionalization but not on economic growth.

\subsection{Other Determinants of Economic Growth}

Corruption is an important factor in economic growth. The work of Mauro (1995) suggest that corruption could increase growth in some cases. Davoodi and Tanzi (1997) find that corruption results in misallocations of public funds which fosters low productivity projects. Corruption can also have a differential impact on growth based on the region or income level of the countries being studied (Karnane \& Quinn, 2019). With regards to some other significant factors, the positive relationship between investment and growth is well-established in the literature (Levine \& Renelt, 1992; Mauro, 1995; Mo \& Papyrakis, 2014). A country's initial level of GDP per capita may also impact growth rates, depending on whether the country is experiencing increasing or decreasing returns to scale (Ades \& Glaeser, 1999). 
A study of particular relevance to this current paper is Schuler and Weisbrod's (2010) work involving migration. They include a migration dummy to capture whether a country is a high immigration receiving country or not. Using this dummy variable, they find a negative direct impact of migration on economic growth both through the dummy and via an interaction variable (migration dummy* ethnic fractionalization).

\section{Testable Hypotheses}

There are several hypotheses which are empirically tested in the paper. These hypotheses are coming out of the existing literature and building on it. In order to facilitate these connections, Table 1 lists the papers relevant to each of the hypotheses.

H1. Political instability lowers GDP growth. The literature discussed in the prior section and listed in Table 1 have consistently found this result.

$\mathrm{H} 2$. Linguistic and religious fractionalization increase political instability. Fractionalization has been found by the literature to increase political instability.

H3. Migration will have a significant direct and indirect impact on economic growth. There is not a great deal of literature on this hypothesis. Schuler and Weisbrod (2010) found some negative direct impacts of migration on economic growth. The literature has not tested the indirect effect of migration on economic growth through its impact on fractionalization and political instability.

H4. Linguistic and religious fractionalization are endogenous. Campos, Saleh and Kuzeyev (2011) treated ethnic fractionalization as an endogenous variable with respect to economic growth. They did not use linguistic or religious fractionalization and did not incorporate the role of migration in impacting fractionalization.

H5. Linguistic and religious fractionalization lowers GDP growth. The evidence from the literature is not fully consistent on the impact of fractionalization on growth. However, the majority of the research listed in Table 1 shows that this relationship tends to be negative.

Table 1. Literature Related to Each of the Hypotheses

\begin{tabular}{|l|l|l|}
\hline H1 & H3 & H5 \\
\hline Alesina \& Perotti, & Schuler \& & Easterly \& Levine, \\
1993 & Weisbrod, 2010 & 1997 \\
Alesina et al., 1996 & & Collier 2000, 2001 \\
Roe \& Siegel, 2011 & & Easterly, 2001 \\
Goren, 2014 & & Reynal-Querol, \\
Karnane \& Quinn, & & 2002 \\
2019 & & Alesina et al., 2003 \\
\cline { 1 - 1 } H2 & H4 & Montalvo \& \\
\cline { 1 - 2 } Annett, 2001 & Campos, Saleh, \& & Reynal-Querol, \\
Blanco \& Grier, & Kuzeyev, 2011 & 2005 \\
2009 & & Campos, Saleh, \& \\
Goren, 2014 & & Kuzeyev, 2011 \\
Karnane \& Quinn, & & Mo and Papyrakis \\
2019 & & 2014 \\
& & Bove \& Elia, 2017 \\
\hline
\end{tabular}

The relationships between the variables in the hypotheses can be visualized via Figure 1 below. This figure shows the interrelationships between the variables which can also help to illustrate the relationships that will be tested in the empirical work. 
Figure 1. Relationships between the Variables in the Hypotheses

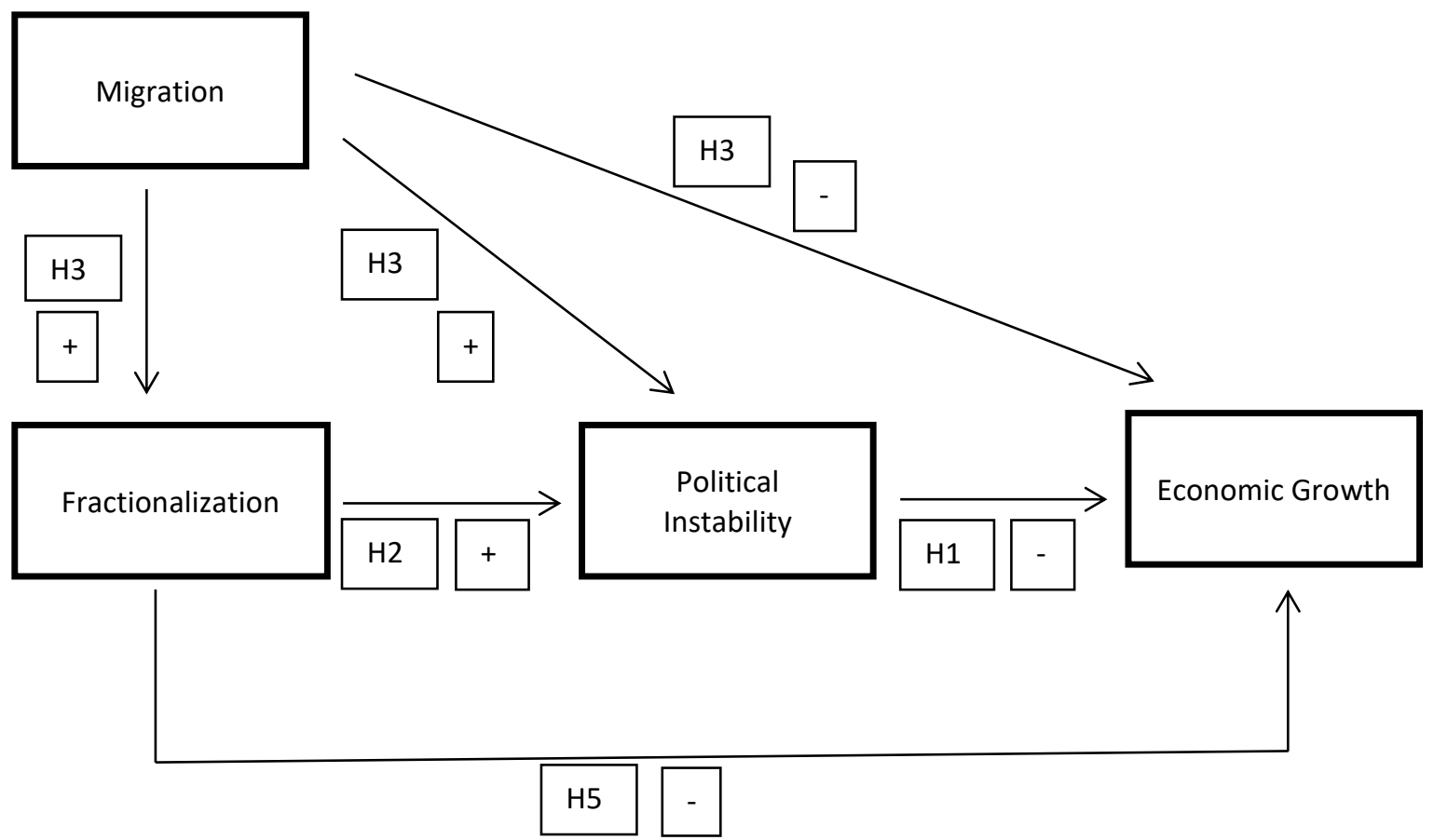

\section{Data and Variables}

In order to test the impact over time and across countries, a panel data set was utilized. This unbalanced panel data set consists of 2,182 observations from 118 countries from 1996-2014. The analysis was run using the software Stata. Table 2 provides summary statistics for all of the variables.

Table 2. Descriptive Statistics

\begin{tabular}{|l|c|c|c|c|}
\hline Variable & Mean & Std. Dev. & Min & Max \\
\hline Religious Fractionalization & 0.48 & 0.23 & 0.02 & 0.83 \\
\hline Linguistic Fractionalization & 0.48 & 0.32 & 0.00 & 0.99 \\
\hline Migrants (percentage) & 0.05 & 0.07 & 0.00 & 0.41 \\
\hline Migrants (standardized) & -0.04 & 0.81 & -2.38 & 2.51 \\
\hline Corruption & 0.01 & 1.02 & -2.59 & 2.06 \\
\hline Initial Income & 24.05 & 2.40 & 19.03 & 30.50 \\
\hline Civil Liberties & 4.84 & 1.63 & 1.00 & 7.00 \\
\hline Political Rights & 4.90 & 1.98 & 1.00 & 7.00 \\
\hline Investment & 3.23 & 0.31 & 1.31 & 4.36 \\
\hline Education & 82.38 & 22.43 & 13.97 & 120.46 \\
\hline Economic Freedom & 60.64 & 9.38 & 21.40 & 83.10 \\
\hline Age & 31.95 & 5.41 & 24.16 & 43.94 \\
\hline
\end{tabular}

\subsection{Dependent Variables}

There are three dependent variables utilized in the analyses: economic growth, religious fractionalization and political instability. Economic growth is the annual percentage change in real GDP per capita (World Development Indicators, 2018a). Religious fractionalization is constructed on a range from zero to 1 . A value of zero indicates no fractionalization (everyone has same religion) while a value of 1 would 
indicate complete fractionalization (each individual having a different religion). Further details on the construction of the religious fractionalization variable can be found in Karnane and Quinn (2019). Political instability is taken from Worldwide Governance Indicators. The variable ranges from -2.5 to 2.5 and is rescaled so that higher values represent more instability. WGI constructs their political instability index using nine different sources representing household and firm surveys, commercial business intelligence firms, nongovernmental organizations (NGOs) and public sector organizations.

\subsection{Independent Variables of Interest}

One of the most important independent variables is corruption. Corruption is measured from -2.5 to 2.5 and is transformed so higher values represent more corruption. This data is taken from Worldwide Governance Indicators. The linguistic fractionalization variable is constructed using data from Ethnologue. The construction of linguistic fractionalization is similar to that of the religious fractionalization variable with values ranging from zero to 1 representing the least fractionalization to the most fractionalization.

There are two different measures of migration tested in the analyses. Both of the migration variables utilize migration stocks. The first measure is the stock of migrants as a percentage of the country's population. This reflects the relative size of the migration population in the country. The second measure is a standardized version of this variable. Migrants as a percentage of the country's population is standardized relative to the country's mean value of this variable throughout the panel timeframe. This is intended to capture the impact of historically significant changes in the amount of migrants in a country, relative to the country's historical values. The migration data is taken from World Development Indicators (World Bank, 2018a).

\subsection{Control Variables}

There are several control variables included in the analysis. Foreign Direct Investment (FDI) in a flow measure, not stock. It is net inflows of FDI into a country in U.S. dollars, converted to log form. This data is taken from World Development Indicators. There is a second measure of investment representing gross capital formation. This measure includes spending on fixed assets plus net changes in inventories. Investment is measured as a percentage of GDP, taken from World Development Indicators. Initial real GDP per capita is also taken from WDI.

Education is represented by the primary school completion rate which is calculated as the number of new entrants in the last grade of primary education as a percentage of the total number of students who are of entrance age to the last grade of primary school. Due to over-aged or under-aged children and repetition of grades, this variable can be greater than 100 percent. However, this variable may be a good measure of how many students reach their last year of primary schooling (at which point they are most likely to finish). From a practical perspective, this is also the most widely available, reliable measure of education across a wide panel sample of countries. The data is taken from the UNESCO Institute for Statistics. A variable for economic freedom was taken from the Heritage Foundation. This index ranges from 0 to 100, with higher values reflecting more economic freedom. This index is based on twelve measures of economic and financial freedoms. For the lagged independent variables in the analysis, one period lags were used as longer lags were insignificant. Also, the analysis was tested with Huber-White heteroscedasticity corrected errors and there were no significant differences suggesting there is not a significant issue of heteroscedasticity in the data. Time effects are controlled for using a linear time trend variable. This was more significant than year dummies, justifying the usage of a trend variable. ${ }^{1}$

\subsection{Instruments}

The four instruments used in the analyses are political rights, civil liberties, average age of the population and a constructed interaction variable. Political and civil rights are both taken from Freedom House. These variables are both scaled from 1 to 7 with higher values indicating more rights (or freedoms, respectively). Average age of the country's population was taken from World Development Indicators. The last instrument is an interaction variable of lagged religious fractionalization and the distance of a country 
from the equator. An additional discussion of these instruments, including their testing, will be done in the methodology section.

\section{Empirical Methodology}

As mentioned in the introduction, the relationships among political instability, fractionalization and economic growth (GDP growth) have received considerable attention in the literature. The problem of endogeneity with respect to fractionalization has not yet been solved in the literature. As discussed in the literature review, past studies have used a two-equation model with political instability and GDP growth as dependent variables. These models treat instability as endogenous with respect to GDP growth while treating religious and linguistic fractionalization as exogenous in these models. But these exogeneity assumptions have not been tested and therefore may not be valid and may result in biased coefficient estimates. Adding the impact of migration to these models is also relatively new in the literature. Does migration affect instability and growth directly or indirectly via higher fractionalization?

Our goal is to add to the literature by constructing and estimating a model which looks at the direct and indirect effects of different migration measures on fractionalization, instability and economic growth while taking care to validate the endogeneity of critical variables in the structural equations making up the models. A series of Hausman-Wu endogeneity tests were run to help guide the model's construction. The null hypothesis of the Hausman-Wu test is that a variable is exogenous. Rejecting this null hypothesis means that a variable could be endogenous. When applied to our variables of interest, Hausman-Wu tests reject the exogeneity of political instability with respect to GDP growth with a p-value of .03 . This suggests that GDP growth is a structural equation in our model with political instability as a key right-hand-side endogenous variable. It also suggests that political instability should appear as a separate structural equation in our model.

The assumption of exogeneity is not rejected for linguistic fractionalization or migration with respect to both political instability and GDP growth. The relevant $p$-values for the Hausman-Wu test on linguistic fractionalization with respect to political instability and GDP growth are .98 and .32 . The $p$-values for the corresponding Hausman-Wu tests of migration are .95 and .94. Therefore, linguistic fractionalization and migration can both be safely treated as exogenous right-hand-side variables in both the GDP growth and political instability equations. For religious fractionalization, the assumption of exogeneity was rejected for GDP growth but not for instability with $p$-values of .01 and .23. This suggests that religious fractionalization is endogenous with respect to economic growth and thus requires its own structural equation in the model.

Accordingly, our three-equation structural model looks like this:

$$
\begin{aligned}
& F_{i, j}^{R}=\alpha_{0}+\alpha_{1} F_{i, j}^{L}+\alpha_{2} M_{i, j}+\alpha_{3} X_{i, j}+\alpha_{5} d_{i}+\varepsilon_{i, j} \\
& S_{i, j}=\beta_{0}+\beta_{1} F_{i, j}^{L}+\beta_{2} F_{i, j}^{R}+\beta_{3} M_{i, j}+\beta_{4} X_{i, j}+\beta_{5} d_{i}+\varepsilon_{i, j} \\
& G_{i, j}=\gamma_{0}+\gamma_{1} F_{i, j}^{L}+\gamma_{2} F_{i, j}^{R}+\gamma_{3} M_{i, j}+\gamma_{4} S_{i, j}+\gamma_{5} W_{i, j}+\gamma_{6} d_{i}+\varepsilon_{i, j}
\end{aligned}
$$

In equation (1), $F_{i, j}^{R}$ and $F_{i, j}^{L}$ are religious and linguistic fractionalization, respectively. $M_{i, j}$ is the migration variable. $X_{i, j}$ is the vector of exogenous control variables and instruments. Country dummies $\left(d_{i}\right)$ and an error term is also included with subscripts referring to country $i$ and year $j$. The country dummies are used to correct for fixed time-invariant effects. In equations (2) and (3), $S_{i, j}$ represents political instability and $G_{i, j}$ is GDP growth and $W_{i, j}$ are the control variables in the GDP equation.

Ordinary least squares (OLS) and two-stage least squares (2SLS) were used to estimate the coefficients. Equation (2) has only exogenous variables on the RHS that are uncorrelated with the error term. Therefore, simple OLS will give appropriate unbiased coefficient estimates. Equations (2) and (3), however, have RHS endogenous variables that are correlated with the error terms and thus require an instrumental variables (2SLS) approach to create unbiased and consistent coefficient estimates. 
2SLS is well known and requires identifying instruments that can proxy for the RHS endogenous variable by producing fitted values of the RHS endogenous variable in the first stage regression. These instruments need to be correlated with the RHS endogenous variable, but uncorrelated with the error term in the structural equation. Moreover, these instruments must be excluded from the structural equation's RHS exogenous variables. Their only purpose is to proxy for the endogenous variable.

As mentioned in the Data and Variables section, there are four instrumental variables used to create fitted values in the first stage regression for both the instability and religious fractionalization RHS endogenous variables in equations (2) and (3). These variables are age, equator*lagged religious fractionalization, civil liberties and political rights. The first two instrumental variables are similar to explanatory variables found in a study of the determinants of religious fractionalization (Campus, Saleh \& Kuzeyev, 2011). The variables civil liberties and political rights were found to be significant predictors of political instability in previous studies (Karnane \& Quinn, 2019).

Note that identification of each equation requires that exclusion restrictions be met. The basic rule is that the number of excluded exogenous variables from the structural equation (the instruments) must be greater than the number of included RHS endogenous variables. This is not relevant for equation (1) since there are no RHS endogenous variables. In equations (2) and (3) the number of excluded variables is greater than the number of RHS endogenous variables. As a check on over identification, the Sargan test was run and passed. Also, an F-test on the first stage regression confirmed that the instruments were jointly significant in determining the fitted values of the RHS endogenous variable.

\section{Results}

The full sample results for each equation (religious fractionalization, political instability, GDP growth) are shown in Tables 3, 4, and 5, respectively. Tables 6-8 show the corresponding equation results for the SubSaharan Africa subsample. The tables are all included at the end of the paper in the appendix. Overall, results are generally consistent with the predictions of the hypotheses. As predicted by the first hypothesis, instability has a significant, negative impact on economic growth. The analyses show instability to be an important factor both in terms of impacting growth directly and acting as a conduit for indirect effects of other variables. The second hypothesis regarding the indirect effects of fractionalization is partially confirmed. Contrary to predictions, religious fractionalization is insignificant with respect to political instability. But linguistic fractionalization is a significant indicator of increased political instability. Thus, linguistic fractionalization has a negative impact on economic growth indirectly via political instability. A similar result is found for the third hypothesis regarding migration. Migration does not have a direct effect on growth. Migration is found to lower growth indirectly via increased political instability. Migration is found to have a negative impact on religious fractionalization but this does not affect growth. With regards to the fourth hypothesis, religious fractionalization is endogenous but linguistic fractionalization is exogenous. The model and estimation methods need to take this finding into account.

\section{Regional Analysis}

Studies of economic growth can sometimes provide different results for sub-Saharan African countries. Therefore, an additional analysis is run on SSA countries only. Linguistic fractionalization and migration both have a positive impact on religious fractionalization for SSA countries. However, in non-SSA countries, linguistic fractionalization is insignificant and migration is negative with regards to religious fractionalization. The impact of corruption varies based on region as well. Consistent with previous research, the direct impact of corruption on economic growth is positive in SSA but insignificant outside of SSA (Karnane \& Quinn, 2019). The process of migration increasing instability and then instability reducing economic growth seems to be concentrated in SSA. Outside of SSA, migration does not have a significant impact on instability. And instability does not have a significant impact on growth. 


\section{Conclusions}

The results of the paper have relevance for both the literature and policy. The analysis finds that migration and linguistic fractionalization negatively affect growth only indirectly via political instability. After accounting for endogeneity, religious fractionalization has no direct or indirect effect on growth. This suggests the importance of distinguishing linguistic and religious fractionalization variables rather than using a combined variable. Overall, the paper supports the view that modelling economic growth is complex and requires a multiple equation structural model which takes proper account of endogeneity issues.

Another important feature of the analysis is that the indirect negative impacts of migration and linguistic fractionalization on growth appear to be driven by results from Sub-Saharan African countries. The migration, linguistic fractionalization, and even instability variables are insignificant for growth outside of this region. Note also that corruption positively impacts growth in SSA but is insignificant outside of the region. This supports the view that growth studies need to test not only large cross-country global samples but also separate out SSA countries for analysis. This is especially true in research involving factors such as corruption and institutions.

Fractionalization and migration do not appear to have a direct negative impact on growth. Their effect is indirect by causing worsened political instability that, in turn, lowers growth. This is especially relevant as increasing number of migrants are moving to other developing countries. This can be seen globally in Syrian refugees moving into countries like Turkey, Jordan and Lebanon. Similar phenomenon can be seen in the Rakhine fleeing to Bangladesh or Somalians in Kenya. As refugee flows increase into less developed countries, international organizations and donors need to focus on more than meeting the needs of the refugees. Assistance needs to be given to the host governments to enhance their stability in the midst of dealing with the strain of refugees and fractionalization. This will require more funding by international organizations and their donor countries. Optimally, this additional assistance would be contingent on the government abiding by a set of institutional rules. In this way, the negative effects of refugee flows and fractionalization on economic growth via political instability can be mitigated to some extent.

\section{End Notes}

1. The analysis also includes country level fixed effects. The country dummy approach to fixed effects is similar to a time-demeaned transformation but instead of $X_{t}-X_{t-1}$ for each variable the transformation is $X_{t}-\bar{X}$ where $\bar{X}$ is the mean value of the variable (Wooldridge, 2012). Interested readers can reference this material in chapter 14 of Wooldridge (2012). The chapter contains a discussion regarding the merits of first differencing and pseudo-first differencing (fixed effects) in dealing with autocorrelation. Wooldridge (2012) then continues with a discussion of the difficulty of determining whether errors are serially correlated when running a fixed effects analyses. Using Wooldridge (2012) as a basis, the usage of fixed effects and a time trend is seen as a reasonable approach to dealing with any potential autocorrelation issues.

\section{References}

Acemoglu, D., \& Robinson, J. (2006). Economic backwardness in political perspective. The American Political Science Review, 100(1), 115-131.

Acemoglu, D., \& Robinson, J. (2012). Why nations fail: The origins of power, prosperity, and poverty. New York, NY: Crown Business.

Ades, A. F., \& Glaeser, E. L. (1999). Evidence on growth, increasing returns, and the extent of the market. The Quarterly Journal of Economics, 114(3), 1025-1045.

Alesina, A., Devleeschauwer, A., Easterly, W., Kurlat, S., \& Wacziarg, R. (2003). Fractionalization. Journal of Economic Growth, 8, 155-194.

Alesina, A., \& La Ferrara, E. (2005). Ethnic diversity and economic performance. Journal of Economic Literature, 43, 762800. 
Alesina, A., Ozler, S., Roubini, N., \& Swagel, P. (1996). Political instability and economic growth. Journal of Economic Growth, 1(2), 189-211.

Alesina, A., \& Perotti, R. (1993). Income distribution, political instability, and investment. NBER Working Paper Series, (4486), 1-33.

Annett, A. (2001). Social fractionalization, political instability, and the size of government. IMF Staff Papers, 48(3), 561592.

Blanco, L., \& Grier, R. (2009). Long live democracy: The determinants of political instability in Latin America. Journal of Development Studies, 45(1), 76-95.

Bossuroy, T. (2011). Individual determinants of ethnic identification. Working Paper 2011-06, Dauphine Universite Paris.

Bove, V., \& Elia, L. (2017). Migration, diversity, and economic growth. World Development, 89, 227-239.

Campos, N. F., Saleh, A., \& Kuzeyev, V. (2011). Dynamic ethnic fractionalization and economic growth. The Journal of International Trade \& Economic Development, 20(2), 129-152.

Collier, P., \& Hoeffler, A. (1998). On economic causes of civil war. Oxford Economic Papers, 50(4), 563-573.

Collier, P. (2000). Ethnicity, politics, and economic performance. Economics and Politics, 12(3), 225-245

Collier, P. (2001). Ethnic diversity: An economic analysis. Economic Policy, 32, 129-166.

Davoodi, H. R., \& Tanzi, V. (1997). Corruption, public investment, and growth. IMF Working Papers, 97(139), 1-23.

Easterly, W., \& Levine, R. (1997). Africa's growth tragedy: Policies and ethnic divisions. Quarterly Journal of Economics, 112(4), 1203-1250.

Easterly, W. (2001). Can institutions resolve ethnic conflict? Economic Development and Cultural Change, 49(4), 687706

Goren, E. (2014). How ethnic diversity affects economic growth. World Development, 59, 275-297.

Karnane, P., \& Quinn, M. A. (2019). Political instability, ethnic fractionalization and economic growth. International Economics and Economic Policy, 16, 435-461.

Kimenyi, M. S. (2006). Ethnicity, governance and the provision of public goods. Journal of African Economies, 15(1), 6299.

Levine, R., \& Renelt, D. (1992). A sensitivity analysis of cross-country growth regressions. American Economic Review, 82(4), 942-963.

Mauro, P. (1995). Corruption and growth. Quarterly Journal of Economics, 110, 681-712.

Mo, P. H., \& Papyrakis, E. (2014). Fractionalization, polarization, and economic growth: Identifying the transmission channels. Economic Inquiry, 52(3), 1204-1218.

Montalvo, J. G., \& Reynal-Querol, M. (2005). Ethnic polarization, potential conflict, and civil wars. American Economic Review, 95(3), 796-816.

Ranis, G. (2009). Diversity of communities and economic development. Yale University Economic Growth Center, (977), $1-17$.

Reynal-Querol, M. (2002). Ethnicity, political systems, and civil wars. Journal of Conflict Resolution, 46(1), 29-54.

Roe, J., \& Siegel, J. (2011). Political instability: Effects on financial development, roots in the severity of economic inequality. Journal of Comparative Economics, 39(3), 279-309.

Schuler, D., \& Weisbrod, J. (2010). Ethnic fractionalization, migration and growth. Empirical Economics, 39, $457-486$.

Touchton, M. (2013). The dangers of diversity: Ethnic fractionalization and the rule of law. Economics, Management and Financial Markets, 8(1), 20-40.

United Nations International Organization for Migration, (2018). World Migration Report. https://www.iom.int/wmr/world-migration-report-2018.

World Bank, (2018a). World Development Indicators. https://data.worldbank.org/products/wdi

World Bank, (2018b). World Bank Country and Lending Groups Classifications. https://datahelpdesk.worldbank.org/knowledgebase/articles/906519-world-bank-country-and-lending-groups 


\section{Appendix}

Table 3. Religious Fractionalization

\begin{tabular}{|c|c|c|}
\hline Variables & Model 1 & Model 2 \\
\hline Linguistic Fractionalization & $\begin{array}{l}0.015 \\
(1.80)^{*}\end{array}$ & $\begin{array}{l}0.014 \\
(1.69)^{*}\end{array}$ \\
\hline Migrants - percentage & $\begin{array}{l}-0.335 \\
(-6.62) * * *\end{array}$ & \\
\hline Migrants - standardized & & $\begin{array}{l}-0.002 \\
(-3.09)^{* * *}\end{array}$ \\
\hline Initial Income & $\begin{array}{l}-0.006 \\
(-2.70)^{* * *}\end{array}$ & $\begin{array}{l}-0.005 \\
(-2.19)^{* *}\end{array}$ \\
\hline Civil Liberties & $\begin{array}{l}-0.004 \\
(-2.86)^{* * *}\end{array}$ & $\begin{array}{l}-0.004 \\
(-2.85)^{* * *}\end{array}$ \\
\hline Political Rights & $\begin{array}{l}-0.003 \\
(-3.46)^{* * *}\end{array}$ & $\begin{array}{l}-0.003 \\
(-3.06)^{* * *}\end{array}$ \\
\hline Age & $\begin{array}{l}0.015 \\
(15.33)^{* * *}\end{array}$ & $\begin{array}{l}0.015 \\
(14.94)^{* * *}\end{array}$ \\
\hline Equator*lagged fractionalization & $\begin{array}{l}2.443 \\
(71.78)^{* * *}\end{array}$ & $\begin{array}{l}2.396 \\
(71.75)^{* * *}\end{array}$ \\
\hline Time Trend & $\begin{array}{l}-0.001 \\
(-3.60)^{* * *}\end{array}$ & $\begin{array}{l}-0.001 \\
(-4.18)^{* * *}\end{array}$ \\
\hline Number of Observations & 2182 & 2182 \\
\hline Prob $>F$ & 0.00 & 0.00 \\
\hline \multicolumn{3}{|c|}{$\begin{array}{l}\text { Note: Coefficients shown with t-statistics in parentheses. }{ }^{*}, * * \text { and } \\
* * * \text { refers to significance at } 10,5 \text { and } 1 \% \text { level. }\end{array}$} \\
\hline
\end{tabular}

Table 4. Political Instability

\begin{tabular}{|l|l|l|}
\hline Variables & Model 1 & Model 2 \\
\hline Linguistic Fractionalization & 0.428 & 0.428 \\
& $(3.61)^{* * *}$ & $(3.65)^{* * *}$ \\
\hline Religious Fractionalization & -0.115 & -0.175 \\
& $(-.61)$ & $(-.93)$ \\
\hline Migrants - percentage & 1.994 & \\
& $(2.82)^{* * *}$ & \\
\hline Migrants - standardized & & 0.060 \\
& & $(5.98)^{* * *}$ \\
\hline Corruption & 0.322 & 0.302 \\
& $(9.16)^{* * *}$ & $(8.59)^{* * *}$ \\
\hline Initial Income & -0.201 & -0.222 \\
& $(-6.40)^{* * *}$ & $(-7.09)^{* * *}$ \\
\hline Civil Liberties & -0.085 & -0.081 \\
& $(-4.44)^{* * *}$ & $(-4.32)^{* * *}$ \\
\hline Political Rights & -0.064 & -0.068 \\
& $(-5.07)^{* * *}$ & $(-5.42)^{* * *}$ \\
\hline
\end{tabular}


Table 4. Political Instability (Continued)

\begin{tabular}{|l|l|l|}
\hline Variables & Model 1 & Model 2 \\
\hline Time Trend & $\begin{array}{l}0.019 \\
(6.01)^{* * *}\end{array}$ & $\begin{array}{l}0.020 \\
(6.45)^{* * *}\end{array}$ \\
\hline Number of Observations & 1813 & 1813 \\
\hline Prob>F & 0.00 & 0.00 \\
\hline $\begin{array}{l}\text { Note: Coefficients shown with z-statistics in parentheses. }{ }^{*}, * * \\
\text { and } * * * \text { refers to significance at 10, } 5 \text { and 1\% level. }\end{array}$ \\
\hline
\end{tabular}

Source: Authors' analysis of data set.

Table 5. GDP Growth

\begin{tabular}{|c|c|c|}
\hline Variables & Model 1 & Model 2 \\
\hline Instability & $\begin{array}{l}-4.1450 \\
(-3.35)^{* * *}\end{array}$ & $\begin{array}{l}-4.1110 \\
(-3.31)^{* * *}\end{array}$ \\
\hline Linguistic Fractionalization & $\begin{array}{l}4.037 \\
(2.31)^{*}\end{array}$ & $\begin{array}{l}3.992 \\
(2.31)^{*}\end{array}$ \\
\hline Religious Fractionalization & $\begin{array}{l}-0.199 \\
(-.07)\end{array}$ & $\begin{array}{l}-0.683 \\
(-.23)\end{array}$ \\
\hline Migrants - percentage & $\begin{array}{l}-7.992 \\
(-.64)\end{array}$ & \\
\hline Migrants - standardized & & $\begin{array}{l}-0.030 \\
(-.16)\end{array}$ \\
\hline Corruption & $\begin{array}{l}0.814 \\
(1.09)\end{array}$ & $\begin{array}{l}0.779 \\
(1.05) \\
\end{array}$ \\
\hline Initial Income & $\begin{array}{l}0.172 \\
(.26)\end{array}$ & $\begin{array}{l}0.147 \\
(.22)\end{array}$ \\
\hline Investment & $\begin{array}{l}3.907 \\
(6.69)^{* * *}\end{array}$ & $\begin{array}{l}3.939 \\
(6.76)^{* * *}\end{array}$ \\
\hline Education & $\begin{array}{l}0.014 \\
(.74)\end{array}$ & $\begin{array}{l}0.016 \\
(.84)\end{array}$ \\
\hline Economic Freedom & $\begin{array}{l}-0.181 \\
(-5.12)^{* * *}\end{array}$ & $\begin{array}{l}-0.184 \\
(-5.26)^{* * *}\end{array}$ \\
\hline Time Trend & $\begin{array}{l}-0.082 \\
(-1.32)\end{array}$ & $\begin{array}{l}-0.084 \\
(-1.35)\end{array}$ \\
\hline Number of Observations & 929 & 929 \\
\hline Prob $>F$ & 0.00 & 0.00 \\
\hline
\end{tabular}

Source: Authors' analysis of data set. 
Table 6. Religious Fractionalization for SSA

\begin{tabular}{|c|c|c|}
\hline Variables & $\begin{array}{l}\text { Sub-Saharan } \\
\text { Africa }\end{array}$ & $\begin{array}{l}\text { Other } \\
\text { Countries }\end{array}$ \\
\hline Linguistic Fractionalization & $5.45 * * *$ & -.59 \\
\hline Migrants - percentage & $2.14^{* *}$ & $-6.81 * * *$ \\
\hline Initial Income & $-4.23 * * *$ & $-2.75 * * *$ \\
\hline Time Trend & -.25 & -.22 \\
\hline Civil Liberties & -.96 & $-2.69 * * *$ \\
\hline Political Rights & -1.39 & $-2.20 * *$ \\
\hline Age & -.20 & $9.32 * * *$ \\
\hline Equator*lagged fractionalization & $38.76 * * *$ & $59.45 * * *$ \\
\hline Number of Observations & 720 & 1462 \\
\hline Prob $>F$ & 0.00 & 0.00 \\
\hline
\end{tabular}

Source: Authors' analysis of data set.

Table 7. Political Instability for SSA

\begin{tabular}{|c|c|c|}
\hline Variables & $\begin{array}{l}\text { Sub-Saharan } \\
\text { Africa }\end{array}$ & $\begin{array}{l}\text { Other } \\
\text { Countries }\end{array}$ \\
\hline Linguistic Fractionalization & $1.96 * *$ & $2.96 * * *$ \\
\hline Religious Fractionalization & -1.07 & -.21 \\
\hline Migrants - percentage & $2.29 * *$ & 0.51 \\
\hline Corruption & $7.80 * * *$ & $5.03 * * *$ \\
\hline Initial Income & $3.87 * * *$ & $-4.06 * * *$ \\
\hline Time Trend & $4.58 * * *$ & $2.59 * * *$ \\
\hline Civil Liberties & -1.22 & $-4.75 * * *$ \\
\hline Political Rights & $-5.02 * * *$ & $-1.65^{*}$ \\
\hline Number of Observations & 222 & 591 \\
\hline Prob $>F$ & 0.00 & 0.00 \\
\hline
\end{tabular}

Source: Authors' analysis of data set. 
Table 8. GDP Growth for SSA

\begin{tabular}{|l|l|l|}
\hline Variables & $\begin{array}{l}\text { Sub-Saharan } \\
\text { Africa }\end{array}$ & $\begin{array}{l}\text { Other } \\
\text { Countries }\end{array}$ \\
\hline Instability & $-2.71^{* * *}$ & -1.25 \\
\hline Linguistic Fractionalization & -.09 & 1.58 \\
\hline Religious Fractionalization & -.27 & -.28 \\
\hline Migrants - percentage & 0.97 & -1.24 \\
\hline Corruption & $2.21^{* *}$ & -.59 \\
\hline Initial Income & -.39 & -.56 \\
\hline Investment & $2.39 * *$ & $5.43^{* * *}$ \\
\hline Education & $1.61^{*}$ & $-2.11^{* *}$ \\
\hline Economic Freedom & -.27 & $-6.49 * * *$ \\
\hline Time Trend & -.40 & 0.19 \\
\hline Number of Observations & 310 & 619 \\
\hline Prob>F & 0.00 & 0.00 \\
\hline $\begin{array}{l}\text { Note: } z-\text { statistics shown. }{ }^{*}, * * \\
\text { and } 1 \% \text { level. }\end{array} * * *$ & refers to significance at 10,5 \\
\hline Source: Authors' analysis of data set. & \\
\hline
\end{tabular}

Several robustness checks were made. Instead of country dummies, regional dummies were included in the analyses and the results were robust. An alternative migration variable was tested as well. The total number of migrants was used. While the results were generally consistent, this variable was not used because it is unweighted by a country's overall population. Therefore, the total migrants variable is biased higher for larger countries. Changes were made to the exclusion restrictions regarding the civil liberties and political rights variables and results were consistent. Other instruments were tested as well. We tested the rural percentage of the population and the female percentage of the population as potential instruments for religious fractionalization. Contrary to other research, we did not find these variables to have a significant impact on religious fractionalization (Bossuroy, 2011). 